\title{
Physical and mechanical properties of membrane polyvinilidene flouride with the addition of silver nitrate
}

\author{
Agung Mataram $^{l}$, S. Rizal ${ }^{b^{*}}$, Estu Pujiono ${ }^{l}$ \\ ${ }^{1}$ Mechanical Engineering Department, Engineering Faculty, Universitas Sriwijaya, Sumatera Selatan, Indonesia \\ ${ }^{2}$ Politeknik Negeri Sriwijaya, Mechanical Engineering Department, Sumatera Selatan, Indonesia
}

\begin{abstract}
The membrane is a layer formed from fine fibers are used as a filter. In this research, measured the tensile strength and pore size of the membrane that is made in three variations of a specimen with a mixed composition of different Polyvinilidene Fluoride $17.5 \%, 20 \%, 22.5 \%$, membrane made using Polyvinilidene Fluoride polimer granules and $N, N$-Dimethylformamide as solvent and silver nitrate. Membrane molded into standardized test specimens and tested with a device Adhesion Tearring Strength Tester. The results show an increase in the value of the tensile test of $404.8356 \mathrm{KPa}$ to the composition of $17.5 \%, 507.3598 \mathrm{KPa}$ for composition of $20 \%$ and $603.7218 \mathrm{KPa}$ to a composition of $22.5 \%$. For testing the microstructure using a Scanning Electron Microscopy with the resulting increase in pore diameter, for the range of $558.4 \mathrm{~nm}-781.8 \mathrm{~nm}$ are void to the composition of $17.5 \%$, range $670.1 \mathrm{~nm}-781.8 \mathrm{~nm}$ without voids for the composition of $20 \%$ and $1.117 \mu \mathrm{m}-1.228 \mu \mathrm{m}$ without voids on a composition of 22.5
\end{abstract}

\section{Introduction}

Microbiological contamination of some water sources that exist at the moment is very worrying to the public, according to some researchers, there are many different species of bacteria which are available in pure water and wastewater [1,2].

This application requires a membrane that can improve water quality. The membrane is a layer formed from the composition or the tangle of fine fibers used as filter or barrier for a variety of applications in the industrial world. polymer has been the material of interest to be analyzed and developed its potential as a membrane filter, application examples that are of concern at this time is a membrane filter water [3].

The main objective to be achieved in this discussionare to develop a new method in the production of membran,andTo determine the mechanical properties of the membran of Polyvinilidene Fluoride (PVDF) against tensile testing.

The membrane is a layer formed from the composition or the tangle of fine fibers used as filter or barrier for a variety of applications in the industrial world.

Membrane Polymer produced using Polyvinilidene Fluoride as fiber polymer and DMF as a solvent, the process of printing the membrane by the method of a flat sheet, the membrane of this type is typically used in ultrafiltration process, due to higher porosity and pore structure are interconnected, resulting in permeability is higher for water filtration [4]. be used to determine the characteristics of the membrane there are a number of ways, but a commonused permeability and permeselectivity..

\section{Methodology}

\subsection{Membran Preparation}

Dominated by the carbon fiber Polyvinilidene Fluoride fibers due to a combination of the polymer, has good mechanical properties, especially tensile strength [3]. The advantage of the PVDF fiber, high degree of molecular orientation and a higher melting point (PVDF) fiber tends to decompose below the melting point, Tm of $317-330^{\circ}$ $\mathrm{C})$, and the results were better than carbon fiber [5], Polyvinilidene Fluoride used Writer (Figure 1)

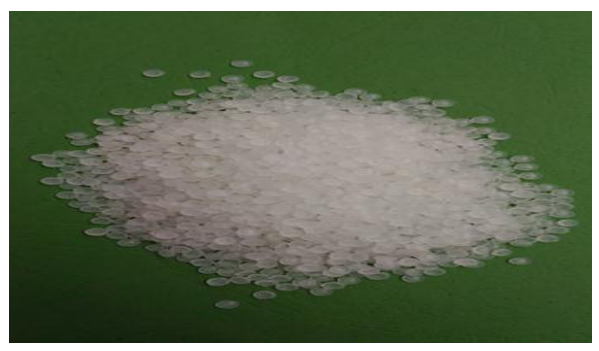

Figure 1 Polyvinilidene Fluoride (PVDF) 
Polyvinilidene Fluoride can to be form thermally stable molecular structure of highly oriented while getting a low temperature heat treatment, which is not significantly impaired during treatment carbonization at a higher temperature, this means the fibers produced have excellent mechanical properties [6,7].

Silver is a chemical element in the periodic table that has the emblem of $\mathrm{Ag}$ and atomic number 47. arms is derived from the Latin Argentum. A transition metal is soft, white, shiny, silver has the highest electrical conductivity and heat throughout the metal and there dimineral and in free form. This metal is used in coins, jewelry, equipment tables, and photography. Silver including precious metals such as gold [8].

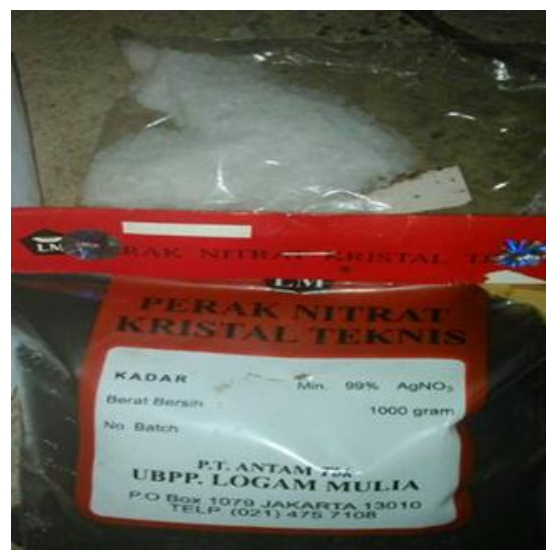

Figure 2 Silver Nitrate

Chemical Properties Silver Nitrate (figure 2):

Very stable in pure air and water so it does not react with air and water at normal temperature. Less reactive than copper, except ozone, sulfur and hydrogen sulfide, which is rapidly discolor the silver surface. Not soluble in dilute acid solution, but can be dissolved in nitric acid and sulfuric acid.

N,N-Dimethylformamide (DMF) supplied by MERCK (figure 3) and is used as a solvent without further purification, thisis a strong solventfor PES polymer, because they have desirable properties such as low volatility, non-flammable, and relatively low toxicity.

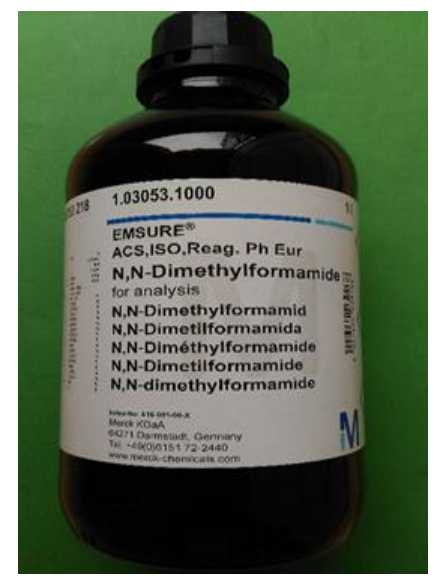

Figure 3 N,N-Dimethylformamide

\subsection{Preparation of Polymer Membranes}

Captions should be typed in 9-point Times. They should be centred above the tables and flush left beneath the figures.

\subsection{Positioning}

Membranes are made in this study using two materials with different variations of the mixture on each specimen, materials used is PVDF and DMF. This mixing of the two materials using a Magnetic Stirrer, this tool will mix the two ingredients with the rotation system so that the mixture becomes homogeneous [9].

Methods flat sheet is one way in the process of making the membrane author uses glass plates and duct tape as a template membrane, membrane PVDF prepared by phase inversion method immersion in a tub of coagulation of water, the result of printing membranes with these methods form a flat sheet [9]

Tensile test is a method used to test the strength of a material by providing load coaxial style. This experiment used to measure the mechanical strength of a material is the force of static given slowly, the results of tensile testing is essential to engineering and product design for yield strength data material tensile testing done to complete the design information is basic mechanical strength of a material and as a data support for material specifications.

Microstructure Test tool SEM (Scanning Electron Microscope), which uses an electron microscope. SEM testing is done in stages on each membrane composition. SEM testing is used to view and analyze surface and texture, shape and size of objects to analyze the sample and analyze the composition of the surface of objects both quantitatively and qualitatively. At this time SEM Test, used to see the size of the pores, voids or holes in the membrane and the bond that exists every pore in the membrane.

Research conducted procedure comprising the steps the steps below:

Preparation of the membrane material, Polyvinilidene Fluoride and $N, N$ - Dimethylformamide and prepare materials stirrer (magnetic stirrer).

Considering mixture of PVDF and DMF prior to the mixing process takes place.

Stir the two ingredients for 6 hours under on each specimen. Print the membrane solution that has been homogenized using glass mold that has been provided.

Prepare a tensile testing machine tearing adhesion strength test (figure 4 ). After that perform appropriate testing procedures. Prepare test equipment SEM, once ready to do appropriate testing procedure. 


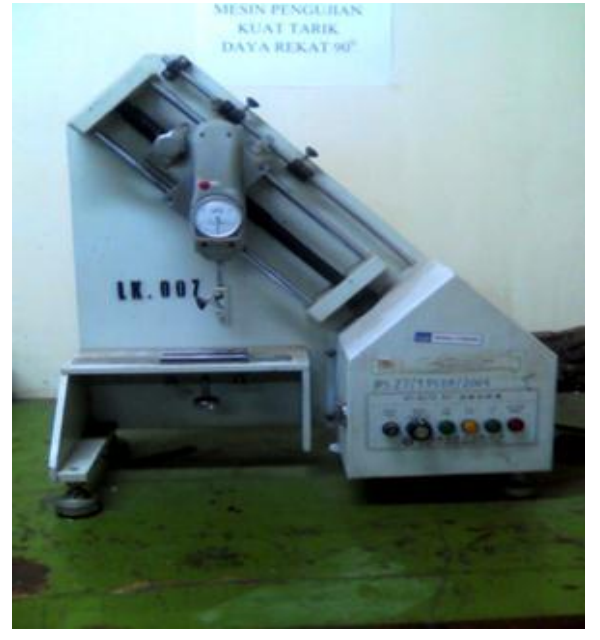

Figure 4 Adhesion Tearring Strenght Test.

\section{RESULTS AND DISCUSSION}

The test results of the research shows the mechanical properties of the material PVDF membrane material, each specimen using a membrane tensile testing machine tearing Adhesion strength test (figure 6). This test is generally aimed at determining the mechanical properties of a material, specifically on this study aims to determine the tensile resistance of the membrane, and to add the test results do also test Scanning Electron Microscopy (SEM). Results SEM micrograph of the surface of PVDF fiber is shown in Figure 5, when the PES fiber content is at $17.5 \%, 20 \%$ and $22.5 \%$ PVDF nanoparticle dispersions relatively simple homogeneous, but with the added amount (\%.PES) in a solution with a composition of $22.5 \%$, occur agglomeration excessive resulting solution is more difficult to be homogeneous $[10,11]$.
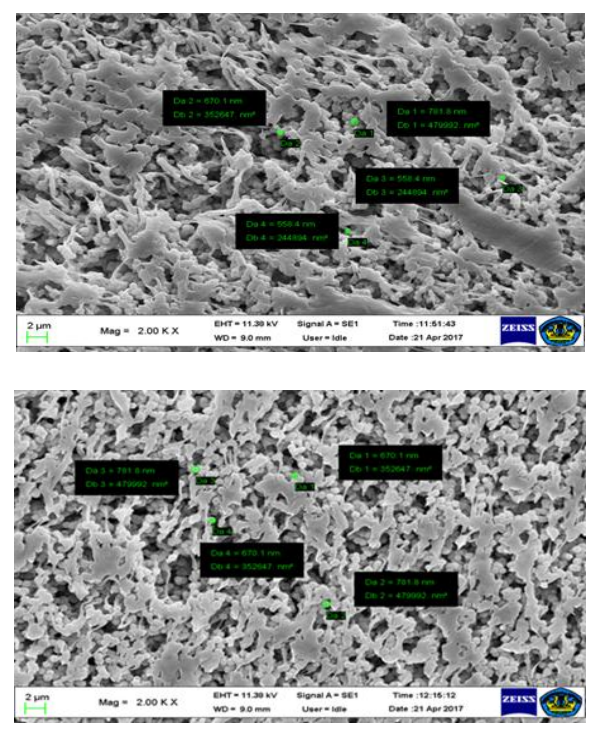

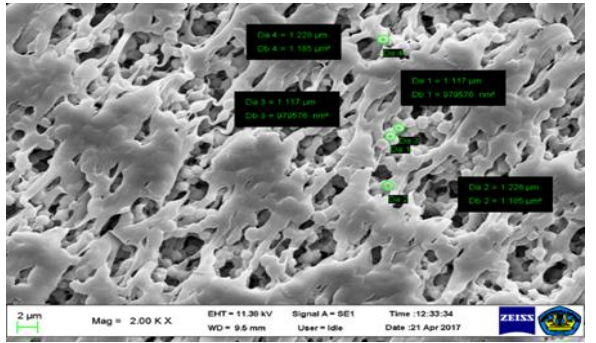

Figure 5 SEM comparison PVDF fibers with different variations $20 \%$ by weight, $22.5 \%$ by weight $25 \%$ by weight.

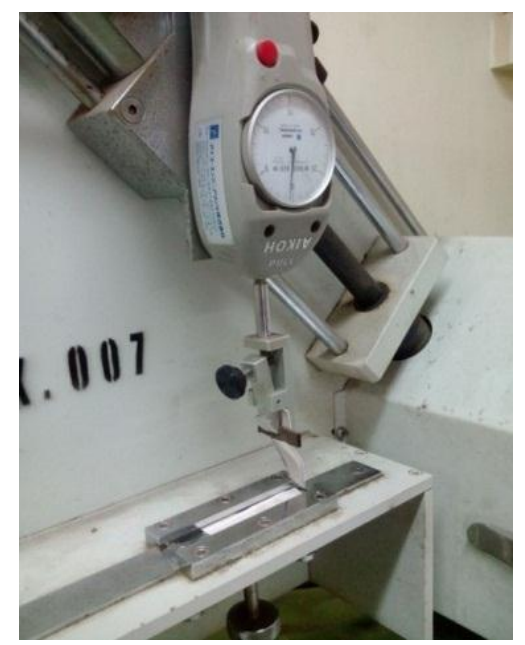

Figure 6 Process Polyvinilidene Fluoride membrane tensile testing

Tensile test specimens having a composition respectively $17.5 \%, 20 \%, 22.5 \%$ PVDF. The tensile strength of the specimens showed increases in the value of $404.8256 \mathrm{kPa}$ to $603.7218 \mathrm{kPa}$ when the specimen with a composition of PVDF fiber increased from $20 \%$ to $22.5 \%$, the value of the tensile strength of the fiber membranes with composition (weight \%) $25 \%$ PVDF also showed an increase up 603.7218 Kpa. PVDF on each specimen resulting fiber braid structure of the membrane increasingly meeting [12].

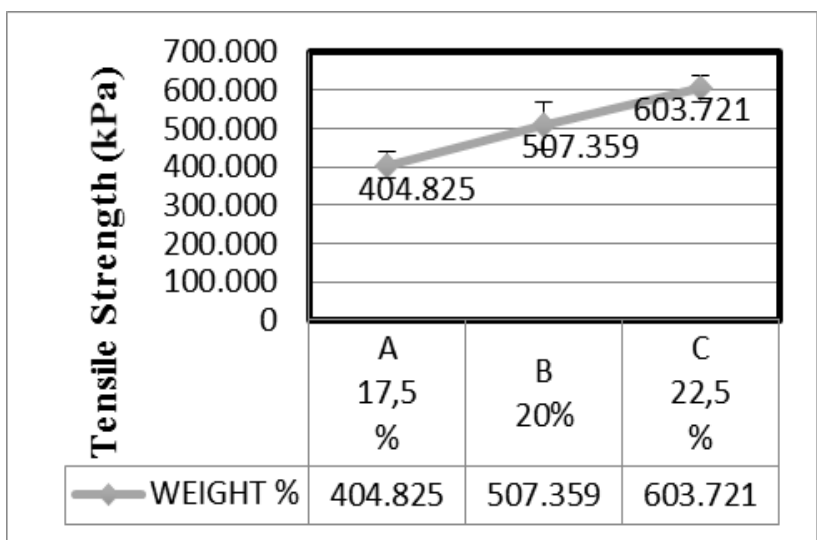


Figure 8 Graph tensile strength (A) of the PVDF composite fiber with changes in The composition (weight \% . PVDF) on each specimen.

\section{Conclusion}

The length of time and the rotation speed of the mixing process of membrane material influence on the results of the homogeneity of the membrane solution.

The temperature at the time of stirring is also important to remove residual solvent and trapped air that can cause bubbles on the membrane

Results of testing the best there is in the composition of $20 \%$ PVDF because it can withstand loads of up to $312.2881 \mathrm{kPa}$

\section{References}

[1] S. Agustina, S. Pudji, T. Widianto, A. Trisni. Penggunaan Teknologi Membran Pada Pengolahan Air Limbah Industri Kelapa Sawit, Workshop Teknologi Industri Kimia dan Kemasan, Jakarta (2008)
[2] V. Bonnélye, L. Gueya. And J. Del-Castillo, Desalination. 222, 59-65 (2008)

[3] A. E. Kalyuzhny, Handbook Of Elispot: Methods and Protocol. Humana Press. Totowa : New Jersey, p 3749 (2005)

[4] M. Mulder, Basic Principles of Membrane Technology. ( $1^{\text {st }}$ ed.) London: The Netherlands, Kluwer Academic Publisher. p 12-17, p 138-140 (1991)

[5] M. Nasir, Sintesi dan Karakteristik Nanokomposit Konduktif Nanofiber, Pusat Penelitian Kimia Lembaga Ilmu Pengetahuan Indonesia, Bandung, (2013)

[6] M. Schwatz, Encyclopedia Of Smart Materials Volume 1 and Volume 2. John Wiley \& Sons. Inc : New York, p 807-824 (2002)

[7] S. Redjeki, Proses Desalinasi Dengan Membran. Direktorat Jendral Pendidikan Tinggi Departemen Pendidikan Nasional (2011)

[8] H. V. Tiwary, P. D. Mangalgiri, A. R. Upadhya, A. Selvaraja, Smart Material, Structures And Systems. Allied Publisher Limited. New Delhi : India (1999)

[9] Y. Wu, Lithium-ion Batteries: Fundamentals and Applications, CRC Press, Boca Raton (2015)

[10] S. Zemansky, Fisika untuk Universitas I: Mekanika, Panas, Bunyi. Bandung: Binacipta (1994) 